ҚАЗАҚСТАН РЕСПУБЛИКАСЫ

ҰЛТТЫҚ ҒЫЛЫМ АКАДЕМИЯСЫНЫН

АБАЙ АТЫНДАҒЫ ҚАЗАҚ ҰЛТТЫҚ

ПЕДАГОГИКАЛЫҚ УНИВЕРСИТЕТІНІҢ

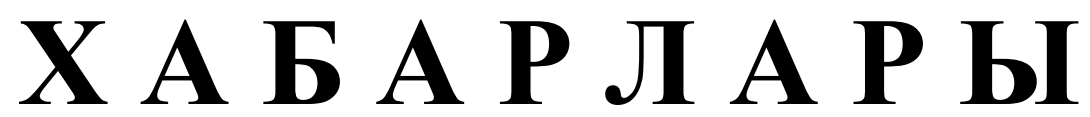

\section{ИЗВЕСТИЯ}

НАЦИОНАЛЬНОЙ АКАДЕМИИ НАУК РЕСПУБЛИКИ КАЗАХСТАН

КАЗАХСКИЙ НАЦИОНАЛЬНЫЙ

ПЕДАГОГИЧЕСКИЙ УНИВЕРСИТЕТ ИМ. АБАЯ

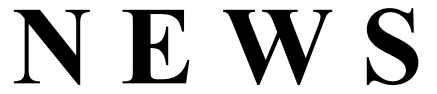

OF THE NATIONAL ACADEMY OF SCIENCES OF THE REPUBLIC OF KAZAKHSTAN

ABAY KAZAKH NATIONAL PEDAGOGICAL UNIVERSITY

ҚОҒАМДЫҚ ЖӘНЕ ГУМАНИТАРЛЫҚ ҒЫЛЫМДАР СЕРИЯСЫ

СЕРИЯ ОБЩЕСТВЕННЫХ И ГУМАНИТАРНЫХ НАУК

SERIES OF SOCIAL AND HUMAN SCIENCES

\author{
6 (322) \\ ҚАРАША - ЖЕЛТОҚСАН 2018 ж. \\ НОЯБРЬ - ДЕКАБРЬ 2018 Г. \\ NOVEMBER - DECEMBER 2018 \\ ИЗДАЕТСЯ С ЯНВАРЯ 1962 ГОДА \\ PUBLISHED SINCE JANUARY 1962 \\ ЖЫЛЫНА 6 РЕТ ШЫҒАДЫ \\ ВЫХОДИТ 6 РАЗ В ГОД \\ PUBLISHED 6 TIMES A YEAR
}

1962 ЖЫЛДЫҢ ҚАНТАР АЙЫНАН ШЫҒА БАСТАҒАН 
Ба с ре дактор

ҚР ҰҒА кұрметті мүшесі

Балықбаев Т.O.

Р е д а ц и я а лқ а сы:

экон. ғ. докторы, проф., ҚР ҰҒА академигі Баймұратов У.Б.; тарих ғ. докторы, проф., ҚР ҰҒА академигі Байпақов К.М.; филос. ғ.докторы, проф., ҚР ҰҒА академигі Есім Г.Е.; фил. ғ. докторы,, проф., ҚР ҰҒА академигі Қирабаев С.С.; эк. ғ. докторы, проф., ҚР ҰҒА академигі Кошанов А.К.; эк.ғ. докторы, проф., ҚР ҰҒА академигі Нәрібаев К.Н. (бас редактордың орынбасары); филос. ғ.докторы, проф., ҚР ҰҒА академигі Нысанбаев А.Н.; заң ғ. докторы, проф., ҚР ҰҒА академигі Сәбікенов С.Н.; заң ғ. докторы, проф., ҚР ҰҒА академигі Сүлейменов М.К.; эк. ғ. докторы, проф., ҚР ҰҒА академигі Сатыбалдин С.С.; тарих ғ. докторы, проф., ҚР ҰҒА академик Әбжанов Х.М.; тарих ғ. докторы, проф., ҚР ҰҒА корр. мүшесі Әбусеитова М.Х.; тарих ғ. докторы, проф., ҚР ҰҒА академик Байтанаев Б.А.; филол. ғ. докторы, проф., ҚР ҰҒА корр. мүшесі Жақып Б.А.; фил. ғ. докторы, проф., академик НАН РК Қалижанов У.К.; филол. ғ. докторы, проф., ҚР ҰҒА академик Қамзабекұлы Д.; тарих ғ. докторы, проф., ҚР ҰҒА академик Қожамжарова Д.П.; тарих ғ. докторы, проф., ҚР ҰҒА академик Койгелдиев М.К.; фил. ғ. докторы, проф., ҚР ҰҒА корр. мүшесі Кұрманбайұлы Ш.; тарих ғ. докторы, проф., ҚР ҰҒА корр. мүшесі Таймағанбетов Ж.К.; социол. ғ. докторы, проф., ҚР ҰҒА корр. мүшесі Шәукенова 3.К.; фил. ғ. докторы, проф., КР ҰҒА корр. мүшесі Дербісәлі А.; саяси. ғ. докторы, проф., Бижанов А.К., тарих ғ. докторы, проф., Кабульдинов 3.Е.; фил. ғ. докторы, проф., ҚР ҰҒА корр мүшесі Қажыбек Е.3.

\section{Р едакция ке н е с i:}

Молдова Республикасының ҰҒА академигі Белостечник Г. (Молдова); Әзірбайжан ҰҒА академигі Велиханлы Н. (Азербайджан); Тәжікстан ҰҒА академигі Назаров Т.Н. (Тәжікстан); Молдова Республикасының ҰҒА академигі Рошка А. (Молдова); Молдова Республикасының ҰҒА академигі Руснак Г. (Молдова); Әзірбайжан ҰҒА корр. мүшесі Мурадов Ш. (Әзірбайжан); Әзірбайжан ҰҒА корр. мүшесі Сафарова 3. (Әзірбайжан); э. ғ. д., проф. Василенко В.Н. (Украина); заң ғ. докт., проф. Устименко В.А. (Украина)

«Қазақстан Республикасы Ұлттық ғылым академиясының Хабарлары. Қоғамдық және гуманитарлық ғылымдар сериясы». ISSN 2224-5294

Меншіктенуші: «Қазақстан Республикасының Ұлттық ғылым академиясы» РҚБ (Алматы қ.)

Қазақстан республикасының Мәдениет пен ақпарат министрлігінің Ақпарат және мұрағат комитетінде 30.04.2010 ж. берілген № 10894-Ж мерзімдік басылым тіркеуіне қойылу туралы куәлік

Мерзімділігі: жылына 6 рет.

Тиражы: 500 дана.

Редакцияның мекенжайы: 050010, Алматы қ., Шевченко көш., 28, 219 бөл., 220, тел.: 272-13-19, 272-13-18, http://nauka-nanrk.kz. social-human.kz

(C) Қазақстан Республикасының Ұлттық ғылым академиясы, 2018

Типографияның мекенжайы: «Аруна» ЖК, Алматы қ., Муратбаева көш., 75. 
Главный редактор

Почетный член НАН РК

T.O. Балыкбаев

Р е дак ци онн а я коллег и я:

докт. экон. Н., проф., академик НАН РК У.Б. Баймуратов; докт. ист. н., проф., академик НАН РК К.М. Байпаков; докт. филос. Н., проф., академик НАН РК Г.Е. Есим; докт. фил. Н., проф., академик НАН РК С.С. Кирабаев; докт. экон. Н., проф., академик НАН РК А.К. Кошанов; докт. экон. Н., проф., академик НАН РК К.Н. Нарибаев (заместитель главного редактора); докт. филос. н., проф., академик НАН РК А.Н. Нысанбаев; докт. юр. Н., проф., академик НАН РК С.Н. Сабикенов; докт. юр. н., проф., академик НАН РК М.К. Сулейменов; докт. экон. Н., проф., академик НАН РК С.С. Сатубалдин; докт. ист. н., проф., академик НАН РК Х.М. Абжанов; докт. ист. н., проф., чл.-корр. НАН РК М.Х. Абусеитова; докт. ист. н., проф., академик НАН РК Б.А. Байтанаев; докт. фил. н., проф., чл.-корр. НАН РК Б.А. Жакып; докт. фиолол. н., проф., академик НАН РК У.К. Калижанов; докт. фил. н., проф., академик НАН РК Д. Камзабекулы; докт. ист. н., проф., академик НАН РК Д.П. Кожамжарова; докт. ист. н., проф., академик НАН РК М.К. Койгельдиев; докт. филол. н., проф., чл.-корр. НАН РК Ш. Курманбайулы; докт. ист. н., проф., чл.корр. НАН РК Ж.К. Таймаганбетов; докт. социол. н., проф., чл.-корр. НАН РК З.К. Шаукенова; д. филол. н., проф., чл.-корр. НАН РК А. Дербисали; доктор политических наук, проф., Бижанов А.К.; доктор ист. наук, проф., Кабульдинов 3.Е.; доктор филол. н., проф., член-корр. НАН РК Қажыбек Е.3.

Р е дак ци онны й с ов ет

академик НАН Республики Молдова Г. Белостечник (Молдова); академик НАН Азербайджанской Республики Н. Велиханлы (Азербайджан); академик НАН Республики Таджикистан Т.Н. Назаров (Таджикистан); академик НАН Республики Молдова А. Рошка (Молдова); академик НАН Республики Молдова Г. Руснак (Молдова); чл.-корр. НАН Азербайджанской Республики Ш. Мурадов (Азербайджан), член-корр. НАН Азербайджанской Республики 3.Сафарова (Азербайджан); д. э. н., проф. В.Н. Василенко (Украина); д.ю.н., проф. В.А. Устименко (Украина)

Известия Национальной академии наук Республики Казахстан. Серия общественных и гуманитарных наук. ISSN 2224-5294

Собственник: РОО «Национальная академия наук Республики Казахстан» (г. Алматы)

Свидетельство о постановке на учет периодического печатного издания в Комитете информации и архивов

Министерства культуры и информации Республики Казахстан № 10894-Ж, выданное 30.04.2010 г.

Периодичность 6 раз в год

Тираж: 500 экземпляров

Адрес редакции: 050010, г. Алматы, ул. Шевченко, 28, ком. 219, 220, тел. 272-13-19, 272-13-18, www:nauka-nanrk.kz / social-human.kz

(C) Национальная академия наук Республики Казахстан, 2018 г.

Адрес типографии: ИП «Аруна», г. Алматы, ул. Муратбаева, 75

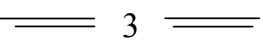


Chief Editor

\section{Honorary member of NAS RK \\ Balykbayev T.O}

Editorial board:

Doctor of economics, prof, academician of NAS RK Baimuratov U.B.; doctor of history, prof, academician of NAS RK Baipakov K.M.; doctor of philosophy, prof, academician of NAS RK Esim G.E.; doctor of philology, prof, academician of NAS RK Kirabayev S.S.; doctor of economics, prof, academician of NAS RK Koshanov A.K.; doctor of economics, prof, academician of NAS RK Naribayev K.N. (deputy editor-in-chief); doctor of philosophy, prof, academician of NAS RK Nyssanbayev A.N.; doctor of law, prof, academician of NAS RK Sabikenov S.N.; doctor of law, prof, academician of NAS RK Suleymenov M.K.; doctor of economy, prof, academician of NAS RK Satybaldin S.S.; doctor of history, prof, academician of NAS RK Abzhanov H.M; doctor of history, prof, corresponding member of NAS RK Abuseitova M.H.; doctor of history, prof, academician of NAS RK Baitanaev B.A.; doctor of philology, prof, corresponding member of NAS RK Zhakyp B.A.; doctor of philology, prof, academician of NAS RK Kalizhanov U.K.; doctor of philology, prof, academician of NAS RK Hamzabekuly D.; doctor of history, prof, academician of NAS RK Kozhamzharova D.P.; doctor of history, prof, academician of NAS RK Koigeldiev M.K.; doctor of philology, prof, corresponding member of NAS RK Kurmanbaiuly Sh.; doctor of history, prof, academician of NAS RK Taimaganbetov J.K.; doctor of sociology, prof, corresponding member of NAS RK Shaukenova Z.K.; doctor of philology, prof, corresponding member of NAS RK Derbisali A.; doctor of political science, prof Bizhanov A.K; doctor of History, prof Kabuldinov Z.E.; doctor of philology, prof, corresponding member of NAS RK Kazhybek E.Z.

\section{Editorial staff:}

Academician NAS Republic of Moldova Belostechnik.G (Moldova); Academician NAS Republic of Azerbaijan Velikhanli N. (Azerbaijan); Academician NAS Republic of Tajikistan Nazarov T.N. (Tajikistan); Academician NAS Republic of Moldova Roshka A. (Moldova) Academician NAS Republic of Moldova Rusnak G. (Moldova); Corresponding member of the NAS Republic of Azerbaijan Muradov Sh. (Azerbaijan); Corresponding member of the NAS Republic of Azerbaijan Safarova Z. (Azerbaijan); Associate professor of Economics Vasilenko V.N. (Ukraine), Associate professor of Law Ustimenko V.A. (Ukraine)

News of the National Academy of Sciences of the Republic of Kazakhstan. Series of Social and Humanities. ISSN 2224-5294

Owner: RPA "National Academy of Sciences of the Republic of Kazakhstan" (Almaty)

The certificate of registration of a periodic printed publication in the Committee of information and archives of the Ministry of culture and information of the Republic of Kazakhstan N 10894-Ж, issued 30.04.2010

Periodicity: 6 times a year

Circulation: 500 copies

Editorial address: 28, Shevchenko str., of. 219, 220, Almaty, 050010, tel. 272-13-19, 272-13-18, www:nauka-nanrk.kz / social-human.kz

(C) National Academy of Sciences of the Republic of Kazakhstan, 2018

Address of printing house: ST "Aruna", 75, Muratbayev str, Almaty 
N E W S

OF THE NATIONAL ACADEMY OF SCIENCES OF THE REPUBLIC OF KAZAKHSTAN

SERIES OF SOCIAL AND HUMAN SCIENCES

ISSN 2224-5294

Volume 6, Number 322 (2018), 160 - 164

https://doi.org/10.32014/2018.2224-5294.49

\author{
V.V. Savelyeva \\ student of the 3rd course PhD \\ Eurasian Technological University \\ vika-sova@mail.ru
}

\title{
HISTORICALANDPEDAGOGICAL BASES OF FORMATION AND DEVELOPMENT OF CREDIT TECHNOLOGY IN KAZAKHSTAN
}

\begin{abstract}
The article analyzes the historical and pedagogical basis of the formation and development of credit technology in Kazakhstan, identifying its stages. The relevance of the topic of the article is due to changes in the education system in Kazakhstan, the development of credit technology, as well as the introduction of a three-stage model in higher education, the development of mobility, which will enable future graduates to become qualified and competitive specialists in the world market.

Article purpose - to prove the efficiency of formation and development of credit technology in Kazakhstan, to define features and stages of its formation and development.

Keywords: modern training, credit technology of training, credit, stage, bachelor, efficiency, model, mobility, competitiveness.
\end{abstract}

Modern integration processes in the educational systems of various countries have brought development and use of adequate and equivalent tools and measuring instruments of training to life. They are directed to achievement of the international transparency of the existing national educational systems and their compatibility with the all-European and international standards. Today Kazakhstan is among those states, that fill the educational policy with the corresponding content reflecting such today's global trends as systematics, the academic freedom, alternativeness, mobility of curricula. Now more and more obvious is a fact that the organization of educational process exists within decades and hasan inheritance from former command system when the teacher was a getter and the transmitter of knowledge, and the student - a passive object. With transition of economy of RK to market system, there is a demand for the expert who would be free in the solution of the tasks, resolute, responsible and independent. Andmore importantly- qualified and demanded in labor market. In these conditions theMinistry of Education and Science of the Republic of Kazakhstan has headed for introduction in HIGHER EDUCATION INSTITUTIONS of such most democratic form which has gained universal recognition and distribution in the world as credit technology of the organization of educational process [1].The solution of this task is promoted by credit technology which represents the educational system directed to increasethe level of self-education and creative development of knowledge by students on the basis of individualization, selectivity of a trajectory of training within a regulation of educational process and accounting of knowledge of students in the type of credit. The word "credit" is translated from Latin (credit) as trust, and respectively this system is built on the basis of the mutual trust between the trainer and trained person.

Each student in this educational technology already participates personally in formation of the individual curriculum, that is an educational trajectory for the entire period of education. Before him opens the freedom of choice of the disciplines given in the curriculum. Accounting of labor input of study is carried out not in time parameters (class periods), butin the volume of the taught material (credits). The credit technology is madewith a new method, not similar to our traditional model of education. In the West it has arisen in the USA about 30 years ago, and then has extended also in Europe, it was to some extent a consequence of broad democratization of educational process at the western universities [2]. This 
educational technology is focused on what forces the person to study independently and to constantly update knowledge.

In Kazakhstan the urgent need for convertibility of High school diplomas, codifications, unification, cataloging of training courses and programs is the converting of introduction of credit technology that, certainly, will allow to remove barriers between the universities of the different countries. And it means that realization at least main actions will involve serious financial and material costs, revision of all system of educational and methodical work in HIGHER EDUCATION INSTITUTION. We cannot do itanymore because Kazakhstan has supported recognition of the Lisbon convention (1997) and the Bologna declaration (1999) which are intended not to create and not to invent new reforms or educational systems, but to unify educational standards and training programs taking into account global trends. The credit technology takes root step by stepin the Republic of Kazakhstan. Since 2003-2004 academic years, the credit system of training began to be applied on economic specialties of separate higher educational institutions in the experiment mode. At the same time each higher education institution applies "conventions in establishment of the credits on subject matters or programs that are the principle of the organization and creation of a training course changes. The teacher will be obliged to provide to students distributing material, a package of documents, and they come to audience prepared. The lecture is under construction in the form of dialogue, "round tables", seminars, and students work in team, solving the given problem. Not only students, but also teachers will be forced to keep up to date. Andundoubted advantage of new system is granted wide freedom of choice. Students are given an opportunity to construct own trajectory of training, to define additional disciplines for specialization in specific industry by the consultant. Visit of these occupations is individual; everyone takes examinations in the scheme, depending on the chosen training trajectory [3].

The student builds the educational program under the direction of an advisor (the teacher of the releasing department provide functions of the mentor of the student on the corresponding specialty, rendering assistance in the choice of a trajectory of training (formation of IUP) and development of the educational program during training). Matters formation of institute of tutors (the teacher conducting studies)is recommended for assistance to students in development of subject.

Thus reforms in education are aimed at the social and economic, spiritual and moral development of society and achievement of the academic and professional mobility of young Kazakhstan citizens in a wide context of the globalized world. They are designed to provide through expansion of access for future experts to resources of a modern civilization optimum balance in accounting of needs of the person, society and the country.

The systems of the credits existing and used worldwide differ not only in the basic purpose, but also in approach to a concept and definition of "credit". For the first time, the credit and hour system has arisen in the USA. In 1869 the President of Harvard University Charles Eliot has entered the concept "credit system", and in 1870 - 80 the system according to which the volume of discipline was measured in the credits has been introduced. Since 1892 the stage of broad application "credit system" and its developmenthas begun.For receiving degree, it is necessary to gain the set quantity "credit hours", socalled test units. In the American USCS system (US Credit system) - the credit hour - this measure is based on training time. In the USA the number of the disciplines studied during a semester is usually 4-5, normal loading of a course - about 15 credit hours. It means that students will spendinthe audience about 15 hours weekly. The student who has gathered the specified number the credit hours can receive a certain degree. The credit hour and degree are interconnected. In the USA for receiving bachelor degreeit is required on average the 120 credit hours, the master - from 30 to 35 credit hours, graduate students - from 6 to 12 credit hours each semester [4].

The American credits - USCS are easily transferred to the European credits - ESTS and the AsiaPacific credits - UCTS.1 American credit hour is equal to 1 Chinese credit. One American credit hour is equal to 1 Japanese test unit. 1 American credit hour is equal to 2 European credits. 1 American credit hour is equal to 2 Asia-Pacific credits; 1 American credit hour is equal to 4 British credits.

In a bachelor degree 1 credit hour is equal to 1 class period of classroom work of the student a week throughout a semester in Kazakhstan, and each class period of a lecture and practical training is followed by 2 hours (100 minutes) of independent work of the student.Thus, studying of this or that discipline "weighing" 1 credit in $(1+2)$ hours a week for a semester (15 weeks) requires 45 hours. 
In Europe there is another system - ECTS (European Credit Traster's System) which has arisen as the pilot ERASMUS project and undergone experimental testing within 6 years (from 1989/90 to 1994-95 academic year). In its 145 higher education institutions participated in the countries of Europe.Creation of the European higher education area is defined in the Sorbonne and Bologna declaration. It is directly specified in the Bologna declaration on creation "the systems of the credits - such as ECTS". Also it is specified: "The credits can be utilized within the education which is not the highest including education during all life on condition of recognition of the appropriate educational programs by the universities".

Today it is possible to tell with confidence that development of a modern national education system on the basis relies on application of the international standards. Now many Kazakhstan universities actively work and make use of foreign experience of modernization of the education system. In the Republic of Kazakhstan 46 higher education institutions have introduced the credit system of training [5]. Studying and the analysis of introduction of credit technology of training show that worldwide it has the specific features. Nevertheless, the efficiency and expediency of credit technology of training are confirmed by its increasing distribution in an education system of many countries of the world as orientation of educational programs on development in students of skills of independent work which will allow to increase the level of creative activity and self-stimulation in development of knowledge, so and improvement of quality of education that will undoubtedly affect competitively ability of future Kazakhstan experts. Overestimating all parties of credit system of training it is possible to tell everything with bigger confidence about her as about the instrument of improvement of quality of education. This system makes positive impact on all parties of educational activity. Credit technology of training obliges higher education institution to create the most favorable conditions for study of students: to provide them with textbooks and other information sources, to create conditions for self-preparation, reading rooms, Internet connection, work on computers, etc., to provide educational process by teachers of high skill level, the high-quality teaching, various training programs relevant for labor market.

Thus, introduction of credit technology of training causes high requirements and to personnel structure, educational methodically to providing, material and technical resources and the most important to the student and to his responsible attitude to study. At credit technology requirements to independent work of students as performance of homework is also surely estimated amplify (at linear system to student's homework's weren't given, performance of independent work was uncontrolled from the teacher and well the principle "from a session prior to a session" worked). This technology assumes free access to all complex of tutorials, including as traditional (the laboratory equipment, devices, computers, video, a slide projector, an audio equipment), and multimedia, virtual trending complexes, etc. Besides, at credit technology of training is reached unification of volume of knowledge, democratic character of the academic strategy of higher education institution [6]. An important component of credit technology of training is as well reoffer of the mastered credits in other higher education institutions also the accumulative character, guaranteeing the academic recognitionabroad. Due to the transparency of borders of labor market on competitive environment domestic experts not only abroad, but also within the country get. It is caused, at least, by two circumstances. First, inflow of foreign labor annually increases. Secondly, our many citizens get higher education at the known foreignuniversities, and return home. It places more great demands on the domestic system of training which have to be competitive among foreign experts whose diplomas are converted, and the educational program is completely measured in the credits. The conventional advantages of credit technology of training are compliance to the international educational standards and a solution of the problem of recognition of documents on education, standardization of educational programs taking into account global trends, the sequence, step-by-step educational activity of students, the academic freedom and variability of training programs. Advantage of credit technology of training is also that it demands constant improvement of pedagogical skill, professional development of organizers of educational process, exchange of the best practices. Our students have free access to all levels of university education in foreign countries, the right of graduates of a bachelor degree and magistracy for employment in any country. Besides, it is met requirements of employers, foreign investors to professional recognition of qualifications at employment of graduates. Higher education institutions of the republic where the credit technology of training has been introduced, have come to a conclusion that the academic freedom is one of the main advantages of credit technology of training: students have an 
opportunity both to choose teachers, and to form the educational trajectory. Along with standard and working curricula, ittakes root individual curricula of studying (IUP), the formations determining content and the organization of their training.

For the purpose of combination of flexibility of planning with requirements of educational standards and also ensuring variability of training, along with obligatory disciplines, is entered disciplines for choice - elective. Self-record of students on elective disciplines is carried out upon completion of studying of obligatory prerequisites. At the same time results of the chosen trajectory of training are reflected in individual curricula. In this regard higher educational institutions should create models of experts of new generation [7].

However, along with positive aspects of credit system she has the following shortcomings:

- big load of the faculty and also the structural sub separate serving educational process as training is carried out in parallel to: traditional system and credit technology;

- the considerable additional expenses connected with introduction of innovative technologies of training and their further improvement;

- increase in educational and methodical and temporary loading of a professorial structure which is connected with need of preparation by each teacher of distributing materials, syllabuses and methodical instructions on independent work of students that involves increase in each class period for 10 minutes;

- complexity of adaptation of some teachers to new requirements and new technique of a conducting of occupations;

- the difficulties connected with uncertainty of a method of calculation of an academic load of professorial teachers, insufficient readiness of students of 1 course for independent work and personal responsibility for the educational achievements (we will notice that it is especially notable at the initial stage, i.e. at the beginning of a semester);

- unpreparedness of parents to the fact that the first-year student is busy with study throughout allthe day.

The lack of flexibility of an educational trajectory, educational load of students, brevity of the periods of training, separation from production - all this negatively affects thequality of the higher education in general and at the level of readiness of experts in particular. Development of remote forms will help to make training in higher education institution the most convenient and attractive. According to experts, remote education will enter in the 21 st century as one of the most effective (and perspective) systems of training of specialists. It will cause growth of professional motivation of teachers and increase in effectiveness of their scientific and pedagogical activity.

Thus, introduction of credit technology of training allows not only to enter world educational space, but also it is essential to intensify process of training of students in a higher educational institution. The credit technology of training assumes a competition - students choose the teacher at whom they will be engaged. Some have taken painfully the fact that they were chosen. But first-year students don't know yet who is who. There can be also such costs: the high quality, but tough teacher risks to be left without students too. But in about three one or four years everything will rise on the places - will go to the one who demands, but also prepares better.

In the conditions of formation in Kazakhstan of competitive system of generation, distribution and use of knowledge introduction of credit system of training will allow to solve a necessary problem - to turn high school education into process not only educational and educational, but also scientific and informative. His component - training of students ("the thinking labor" in the future) not only to scientific knowledge per se, but also methodology of their receiving and application to impart him ability to continuous self-education and professional growth in the conditions of systematical transformation of the society. Only following it, it will be possible to speak about self-sufficiency of education as social institute and its qualities.

\section{REFERENCES}

[1] Vulfson B.L. The strategy of development of education in the West on the dawn of the 21st century. Moscow: URAO publishing house, 2009. 236 pages.

[2] Bases of credit system of training in Kazakhstan. / Under a general edition of Zh.A. Kulekeev, G.N. Gamarnik, B.S. Abdrasilov. Almaty: 1 Cossack. University i, 2014. 100 pages. 
[3] Scherbakov N.P. Bologna Process: from Paris to Bergen: information state-of-the-art review. Barnaul: Altai GTU, 2004.

[4] The state program of development of education in the Republic of Kazakhstan for 2005-2010. education.kz

[5] Bases of credit system of training in the Republic of Kazakhstan, Zh.A. Kulekeeva, G.N. Gamarnika, B.S. Abdrasilova, Almaty, "The Cossack universiteti", 2004.

[6] Asanov N.A., Kaldiyarov D.A., Minazheva of G.S. Organization of educational process on the basis of credit technology. Almaty: Cossack universiteti, 2014.

[7] DadebayevZh. D., Isaeva Z.A., etc. Scientific bases of development of model of development of the higher professional (university) education. In сб. scientific works "The higher school: time of changes"' Under a general edition of T.S. Sadykov. Almaty: КазНПУ of Abay, 2004. Page 98-151.

\section{В.В. Савельева}

$\mathrm{PhD}$ докторантурасының 3 курс студенті

Еуразия технологиялық университеті

\section{ҚАЗАҚСТАНДАҒЫ КРЕДИТ ТЕХНОЛОГИЯСЫН ПАЙДАЛАНУ ЖӘНЕ ДАМУЫНЫН ТАРИХИ ЖӘНЕ ПЕДАГОГИКАЛЫК БАЗАСЫ}

Аннотация. Мақалада Қазақстандағы кредиттік технология дамуының тарихи-педагогикалық негіздері талданады, және оның дамыту кезеңдері анықталды.Мақала тақырыбының өзектілігі. Қазақстандағы білім беру жүйесіндегі өзгерістерге, кредиттік технологияны дамытуға, сондай-ақ жоғары білім берудегі үш деңгейлі модельді енгізудегі ұтқырлықты дамытуға байланысты, өйткені бұл болашақ түлектердің білікті мамандануға және әлемдік нарықта бәсекеге қабілетті болуына байланысты..

Мақаланың мақсаты - Қазақстандағы кредиттік технологияны құрудың және дамытудың тиімділігін негіздеу, оны дамыту ерекшеліктері мен кезеңдерін анықтау.

Түйін сөздер: қазіргі заманғы білім, кредиттік оқыту технологиясы, несие, кезеңдер, бакалавр, тиімділік, модель, ұтқырлық, бәсекеге қабілеттілік.

\section{В.В. Савельева}

студент 3 курса $\mathrm{PhD}$

Евразийский технологический университет

\section{ИСТОРИЧЕСКИЕ И ПЕДАГОГИЧЕСКИЕ ОСНОВЫ ФОРМИРОВАНИЯ И РАЗРАБОТКИ КРЕДИТНОЙ ТЕХНОЛОГИИ В КАЗАХСТАНЕ}

Аннотация. В статье проанализированы историко-педагогические основы становления и развития кредитной технологии в Казахстане, определены ее этапы. Актуальность темы статьи обусловлена изменениями системы образования в Казахстане, становлением кредитной технологии, а также внедрение трехступенчатой модели в высшей школе, развитием мобильности, что даст возможность будущим выпускникам стать квалифицированными специалистами и конкурентоспособными на мировом рынке.

Цель статьи - обосновать эффективность становления и развития кредитной технологии в Казахстане, определить особенности и этапы ее становления и развития.

Ключевые слова: современное обучение, кредитная технология обучения, кредит, этап, бакалавр, эффективность, модель, мобильность, конкурентоспособность.

Information about authors:

Savelyeva V.V. - student of the 3rd course PhD, Eurasian Technological University. 


\section{МАЗМҰНЫ}

Беспаева Р.С., Бугубаева Р.О., Мануэль Ф. Грела2. Көрсеткіштердің теңдестірілген жүйесі негізінде Щучинск-Бурабай курорттық аймағын дамытудың кешенді стратегиясын қалыптастыру ................................................................................ 5

Аюпова 3.К., Құсайынов Д.Ө.Азаматтық процесстерді жетілдірудегі интеграцияның кейбір қырлары...................... 13

Құсайынова А. А., Вальдемар Козловски, Геращенко И. П.Қазақстан республикасындағы міндетті әлеуметтік сақтандырудың қаржылық-құқықтық тетіктерінің ерекшеліктері.

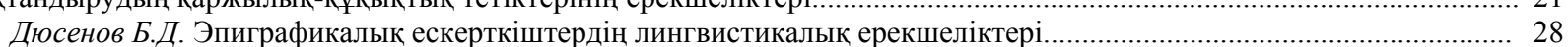

Джумадилова Ш.Г., Атабай Б.Ж. Қазақстандағы халықтың жинақтарының динамикасы......................................... 33

Карабалина А.А., Альситова А. Б., Кереймаганбетова Ж.Н., Абишева Н. М. Құндылық - рухани-адамгершілік

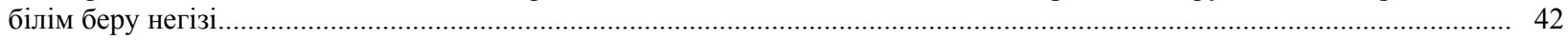

Кенжебаева Д.К., Өрмөрза Б. Ғ., Дашгин Махаммадли. Қазақстандық заманауи жастардың құндылығы............. 51

Нурманова А.Ш., Медерова Д.Е., Дюсенов Б.Д. «Бөкейхан әулетінің талдыбейіт қорымы» эпиграфикалық ескерткіштері тарихи дереккөз ретінде.

Кыдырова Ж.Ш., Онласынов Е.З., Абишова А.У., Шадиева А.А. Оңтүстік Қазақстан облысы сүт және сүт өнімдері нарығындағы жағдайды зерттеу ......

Абимова Г.У., Аманжолов Р., Мынбаева Б.Н., Ибрагимова Д.И. ЖОО-да биолог-студенттердің жобаларды

ұйымдастырылуы мен орындалуына даярлығы.......

Балтабаева А.Ю., Ризаходжаева Г. Мәдени интеграция үдерісіндегі жібек жолының феномені............................... 9

Бурганова Р.И., Абдугалина С.Е., Туякова А.Е. Студенттерге бағытталған білім беру арқылы білім сапасын

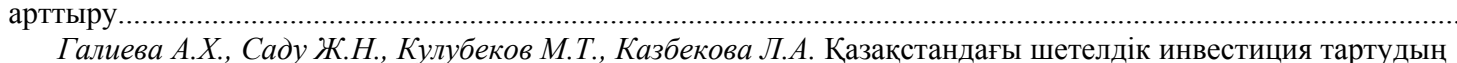

институционалдық жағдайын (талаптарын) бағалау..

Джалилов 3.Г., Батырхан Б.Ш. ХX ғ. екінші жартысындағы шетелдік исламтанушылардың ислам және саясат

туралы теориялық дискурсы.......

Джумабекова А.Т., Канатова А.Ж. Қаржылық ынтымақтастық жағдайларындағы Қазақстан республикасының

ұлттық банкінің өткізу механизмінің өзгеруі......

Дүйсен Г. М., Айтжанова Д. А. Қазақстан және Орталық Азия елдеріндегі көші-қон процесстері дамуының мәселелері мен ерекшеліктері

Есендұлова М.Н. Қазақстандағы « Қиын балаларды» оңалтудың және әлеуметтендірудің психологиялық ерекшеліктері

Жакишева К.М., Жуманова Д.Т., Мукашева Г.М. Экономиканың аграрлық секторының тұрақты дамуына арналған ауыл шаруашылық кәсіпорындарының қаржылық шарттарын мониторингінің рөлі.....

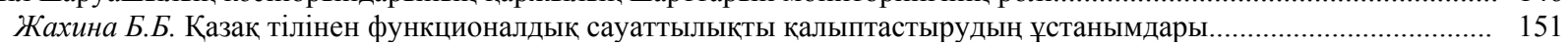

Идресова У.Х., Садуахасова 3.Ж., Муханова А.Т. Криминалистика....................................................................... 156

Савельева В. В. Қазақстандағы кредит технологиясын пайдалану және дамуының тарихи және педагогикалық базасы.

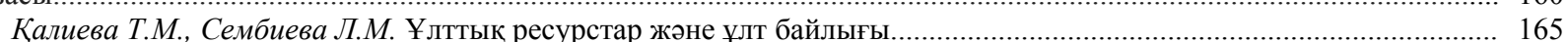

Каримова Р.У., Хаджиева Г.У. ҚХР Ұлттық саясаты контексіндегі ШҰАА-ның этносаяси және әлеуметтікэкономикалық трансформациясы мәселесі.

Керімбек Г., Молдашбаева Л., Джрауова Қ., Ажмухамедова А., Мизанова А. Қазақстан республикасының

республикалық бюджетіне түсетін салық түсімдерінің көрсеткіштерін талдау және бағалау.....

Жолдасбекова С.А., Парманкулова П.Ж., Асаналиев М.К. Мүмкіндігі шектеулі балаларды дамытудағы ұлттық ойындар

Молдакенова Е.К., Байгабулова К.К., Онаева Б.Т. БҚО-да инновациялық үрдістерді басқарудың аймақтық

аспектілігі жүйесінің дамудың жолдары.

Мұратова Г.К., Шаушенова А.Г., Жумасеитова С.Д., Онұварбаева М.Б.Білім беру үрдісінде бұлттық

технологияларын қолдану......

Несіпбеков E. Н., Аппакова Г.Н. Кәсіпорынның инвестициялық портфелін қалыптастырудың теориялық

Нургабылов М.Н., Барлыков Е.К., Егембердиева С.М. ҚР есеп өнеркәсібінің дамуының басқаруының трендсі....... 220

Нурымбетов Т.Я., Абишова А.У., Уразбаева Г.Ж., Кыдырова Ж.Ш., Байнеева П.Т., Абишо Н.У. Модернизациялық

жағдайындағы қр халқын әлеуметтік қолдауының басымдықтары.....

Рахимова С. А., Тургумбекова М. М. Қазақстан республикасындағы шағын және орта бизнестіңмемлекеттік қолдау

бағдарламалары және олардың тиімділігін жүзеге асыру шаралары.......................................................................... 233

Руденко Е.И. Орталық пен Оңтүстік Азия мемлекеттері арасындағы ұғынудың бұрмалануы - «Жұмсақ күш»

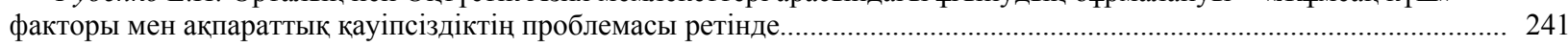

Тохтабаева Ш. Қазына-сандық.......................................................................................................... 251

Утепкалиева К.М., Сабирова Р.К., Кенбаева Г.У. Мұнай-газ секторындағы мемлекеттік-жеке серіктестікті дамыту

Мыңбаев Д. Е. Банкте басқару есебін ұйымдастыру тұжырымдамасы...

Султанова Г.С. Жаңа формацияның экономисі - бакалаврдың кәсіби құзыреттілігін қалыптастырудың

Шаяхметова А.А. Университет жағдайында инклюзивті білім беру үшін педагогтарды оқыту....... 


\section{СОДЕРЖАНИЕ}

Беспаева Р.С., Бугубаев Р.О., Мануэль Ф. Грела. Формирование комплексной стратегии развития ЩучинскоБоровской курортной зоны на основе сбалансированной системы показателей. Аюпова 3.К., Кусаинов Д.У., Уинстон Наган. Некоторые грани интеграции в совершенствовании гражданского процесса.

Кусаинова А.А., Козловски Вальдемар, Геращенко И.П. Обзор некоторых особенностей финансово-правового механизма обязательного социального страхования в республике Казахстан......

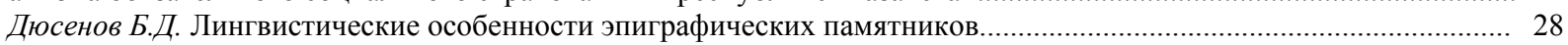

Джумадилова Ш.Г., Атабай Б.Ж.Динамика сбережений населения в Казахстане................................................... 33

Карабалина А.А., Альситова А. Б., Кереймаганбетова Ж.Н., Абишева Н. М. Ценность как базовая основа духовнонравственного образования.

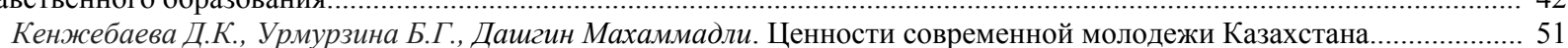

Нурманова А.Ш., Медерова Д.Е., Дюсенов Б.Д. Эпиграфические памятники «Некрополи талдыбейит династии

Бокейхановых» как исторический источник.

Кыдырова Ж.Ш., Онласынов Е.З., Абишова А.У., Шадиева А.А.Исследование ситуации на рынке молока и молочной продукции южно-казахстанской области

Абишова Г.У., Аманжолов Р., Мынбаева Б.Н., Ибрагимова Д.И. Готовность студентов-биологов к организации

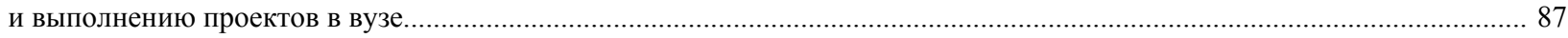

Балтабаева А.Ю., Ризаходжаева Г. Феномен великого шелкового пути в процессе культурной интеграции............... 91

Бурганова Р.И., Абдугалина С.Е., Туякова А.Е. Повышение качества образования посредством

студентоцентрированного обучения...

Галиева А.Х., Саду Ж.Н., Кулубеков М.Т., Казбекова Л.А. Оценка институциональных условий привлечения

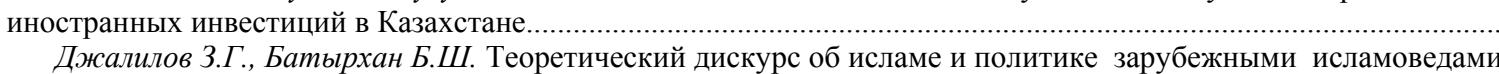
второй половины ХX в.

Джумабекова А.Т., Канатова А.Ж. Трансформация трансмиссионного механизма национального банка республики

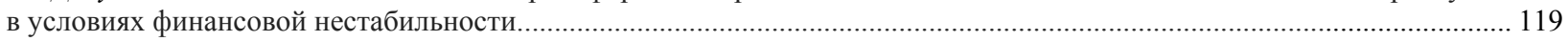

Дуйсен Г.М., Айтжанова Д.А. Проблемы и особенности развития миграционных процессов в Казахстане

и странах Центральной Азии.

Есенгулова М.Н. Психологические особенности реабилитации и социализации "Трудных подростков"

в Казахстане".

Жакишева К.М., Жуманова Д.Т., Мукашева Г.М.Роль мониторинга финансового состояния сельскохозяйственных

предприятий в обеспечении устойчивого развития аграрного сектора экономики.........................................................146

Жахина Б.Б. Принципы формирования функциональной грамотности казахского языка.......................................... 151

Идресова У.Х., Садуахасова 3.Ж., Муханова А.Т. Криминалистика......................................................................... 156

Савельева B.B. Исторические и педагогические основы формирования и разработки кредитной технологии

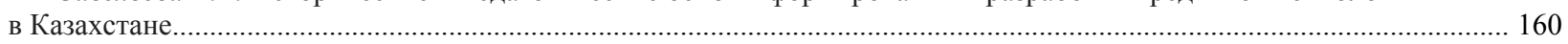

Калиева Т.М., Сембиева Л.М. Национальные ресурсы и богатство нации.................................................. 165

Каримова Р.У., Хаджиева Г.У. К вопросу об этно-политической и социально-экономической трансформации

СУАР в контексте национальной политики КНР

Керимбек Г., Молдашбаева Л., Джрауова Қ., Ажмухамедова А., Мизанова А. Анализ и оценка показателей

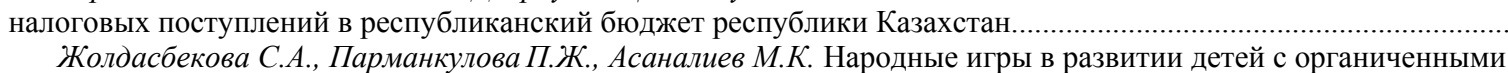

Жолдасбекова С.А., Парманкулова П.Ж., Асаналиев М.К. Народные игры в развитии детей с органиченными

Молдакенова Е.К., Байгабулова К.К., Онаева Б.Т.Пути развития системы регионального аспекта управления

инновационными процессами в АПК.

Муратова Г.К., Шаушенова А.Г., Жумасеитова С.Д., Онгарбаева М.Б. Применение облачных технологий

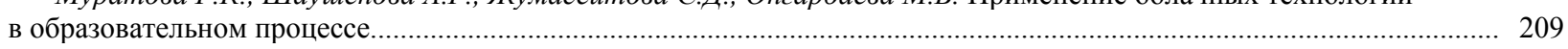

Несипбеков Е.Н., Аппакова Г.Н. Теоретические аспекты формирования инвестиционного портфеля предприятия. 214

Нургабылов М.Н., Барлыков Е.К., Егембердиева С.M. Тенденции управления развитием мясоперерабаты-

вающей отрасли в РК.

Нурымбетов Т.Я., Абишова А.У., Уразбаева Г.Ж., Кыдырова Ж.Ш., Байнеева П.Т., Абишов Н.У. Приоритеты

социальной поддержки населения РК в условиях модернизации................................................................................. 22

Рахимова С. А., Тургумбекова М. М. Программы государственной поддержки мсб в республике Казахстан и меры

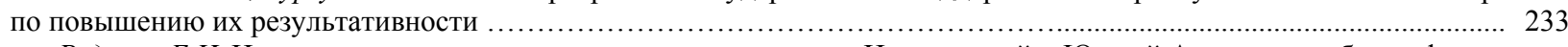

Руденко Е.И. Искаженность восприятия между государствами Центральной и Южной Азии как проблема фактора

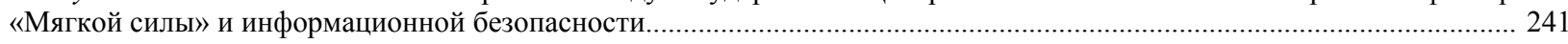

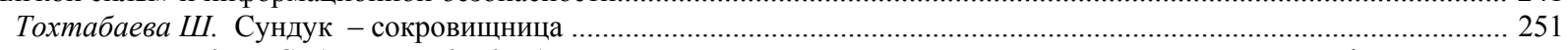

Утепкалиева К.М., Сабирова Р.К., Кенбаева Г.У.Развитие государственно-частного партнерства в нефтегазовой

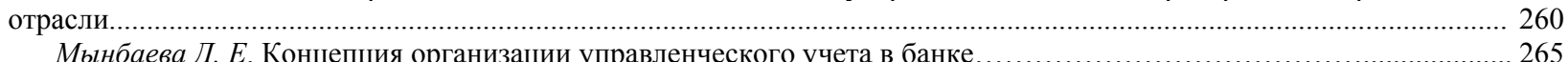

Мынбаева Д. Е. Концепция организации управленческого учета в банке...........................................2.
Султанова Г.С. Педагогические аспекты формирования профессиональных компетенций бакалавра - экономиста

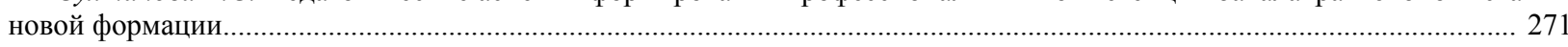

Шаяхметова А.А. О подготовке педагогических кадров к инклюзивному образованию в условиях вуза................ 277 


\section{CONTENTS}

Bespayeva R.S., Bugubayeva R.O., Manuel F. Grela. Formation of the complex strategy for development of the Schuchinsk-

Burabay resort area based on the balanced system of indicators.

Ayupova Z.K., Kussainov D.U., Winston Nagan. Some facets of integration in themodernization ofthe civil process..............13

Kussainova A.A., Kozlowski Waldemar, Gerashchenko I.P. The review of some features of the financial legal mechanism of obligatory social insurance in the republic of Kazakhstan...

Dyussenov B.D. Linguistic features of epigraphic monuments................................................................................ 28

Jumadilova Sh.G., Atabay B.Zh. Dynamics of the population savings in Kazakhstan.......................................................... 33

Karabalina A.A., Alsitova A.B., Kereimaganbetova Zh.N., Abisheva N.M. The values as critical factor of moral education... 42

Kenzhebayeva D.K., Urmurzina B.G., Dashqin Mahammadli. The modern youth values in Kazakhstan............................. 51

Nurmanova A.S., Mederova D.E., Dyussenov B.D. "Bokeykhanov dynasty taldybeyit necropolis" epigraphic monuments

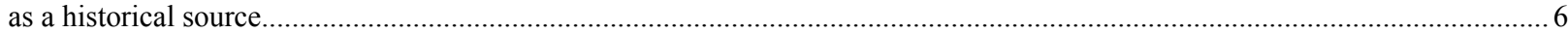

Kydyrova Zh.Sh., Onlasynov E.Z., Abishova A.U., Shadieva A.A.Research of the situation in the market of milk and dairy

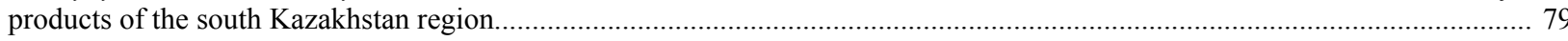

Abishova G.U., Amanzholov R.A., Mynbayeva B.N., Ibragimova D.I. Readiness of students-biologists for the organization

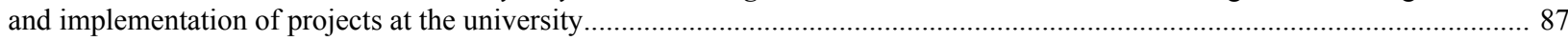

Baltabayeva A.Y., Rizakhojayeva $G$. The phenomenon of the great silk road in the cultural integration process................... 91

Burganova R.I., Abdugalina S.E., Tuyakova A.E. Improving the quality of education through student-centered education... 102

Galiyeva A.Kh., Sadu Zh.N., Kulubekov M.T., Kazbekova L.A. Assessment of the institutional terms of the foreign

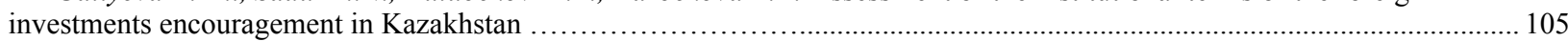

Dzhalilov Z.G. Theoretical discourse on islam and politics in foreign humanism of the second half of 20th century.......... 112

Dzhumabekova A.T., Kanatova A.ZH. Transformation of the transmission mechanism of the national bank of the republic

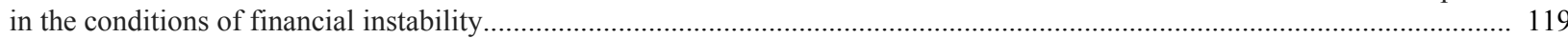

Suleimenov R.B. Problems and features of the development of migration processes in Kazakhstan and Central Asia.......... 124

Yesengulova M.N. Psychological aspects of reintegration and resocialization of "Trouble" adolescents in Kazakhstan....... 134

Zhakisheva K.M., Zhumanova D.T., Mukasheva G.M.The role of monitoring the financial condition of agricultural

enterprises in ensuring sustainable development of the agrarian sector of the economy......................................................... 146

Zhakhina B.B. Principles of functional literacy formation of the kazakh language....................................................... 151

Idresova U.Kh., Saduahasova Z.Zh., Mukhanova A.T. Criminalistics............................................................................. 156

Savelyeva $V . V$. Historicalandpedagogical bases of formation and development of credit technology in Kazakhstan........... 160

Kaliyeva T.M., Sembiyeva L.M. National Resources and national wealth.................................................................. 165

Karimova R., Hajiyeva G. Examining ethno-political and SOCIO-economic transformation of the xinjiang uyghur

autonomous region in the context of the PRC national policies........................................................................................ 176

Kerimbek G., Moldashbayeva L., Jrauova K., Azhmukhamedova A., Misanova A. Analysis and evaluation of reduction

of tax recovery of the republic of kazakhstan on the budget of the republic of Kazakhstan................................................. 185

Zholdasbekova S.A., Parmankulova P.Zh., Assanaliyev M.K. Folk games in the education of children with physical, mental and sensory disturbances..

Moldakenova E.K., Baygabulova K.K., Onaeva B.T. Ways of development of the system of the regional aspect of managing innovative processes in the APC.

Muratova G.K., Shaushenova A.G., Zhumassseitova C.D., Ongarbayeva M.B. Application of cloud technologies in the educational process......

Nurgabylov M.N., Barlikov E.K., Egemberdieva S.M. Trends of management of the development of meat processing industry in RK

Nurymbetov T.Ya., Abishova A.U., Urazbaeva G.Zh., Kydyrova Z.Sh., Baineeva P.T., Abishov N.U. Priorities of social support of the population of republic of Kazakhstan in the conditions of modernization........

Rakhimova S. A., Turgumbekova M. M. Programs of government support for sme in the republic of Kazakhstan and measures to enhance their efficiency.....

Rudenko Ye.I. Misperception between the states of Central and South Asia as a 'Soft power' and information security issue...

Tokhtabayeva Sh. Zh. Treasure-chest.

Utepkalieva K.M., Sabirova R.K., Kenbaeva G.U.Development of public private partnership approach in oil and gas

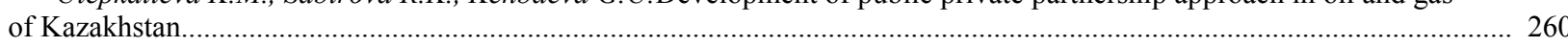

Mynbayeva D.E. Concept of organization of management accounting in bank ........................................................... 265

Sultanova G. S. Pedagogical aspects of formation of professional competence of the bachelor-economist of the new formation

Shayakhmetova A.A. On the training of teaching staff for inclusive education under the conditions of higher education institution. 


\section{PUBLICATION ETHICS AND PUBLICATION MALPRACTICE IN THE JOURNALS OF THE NATIONAL ACADEMY OF SCIENCES OF THE REPUBLIC OF KAZAKHSTAN}

For information on Ethics in publishing and Ethical guidelines for journal publication see http://www.elsevier.com/publishingethics and http://www.elsevier.com/journal-authors/ethics.

Submission of an article to the National Academy of Sciences of the Republic of Kazakhstan implies that the work described has not been published previously (except in the form of an abstract or as part of a published lecture or academic thesis or as an electronic preprint, see $\mathrm{http} / / / \mathrm{www} . e l s e v i e r . c o m / p o s t i n g p o l i c y)$, that it is not under consideration for publication elsewhere, that its publication is approved by all authors and tacitly or explicitly by the responsible authorities where the work was carried out, and that, if accepted, it will not be published elsewhere in the same form, in English or in any other language, including electronically without the written consent of the copyrightholder. In particular, translations into English of papers already published in another language are not accepted.

No other forms of scientific misconduct are allowed, such as plagiarism, falsification, fraudulent data, incorrect interpretation of other works, incorrect citations, etc. The National Academy of Sciences of the Republic of Kazakhstan follows the Code of Conduct of the Committee on Publication Ethics (COPE), and follows the COPE Flowcharts for Resolving Cases of Suspected Misconduct (http://publicationethics.org/files/u2/New_Code.pdf). To verify originality, your article may be checked by the originality detection service Cross Check http://www.elsevier.com/editors/plagdetect.

The authors are obliged to participate in peer review process and be ready to provide corrections, clarifications, retractions and apologies when needed. All authors of a paper should have significantly contributed to the research.

The reviewers should provide objective judgments and should point out relevant published works which are not yet cited. Reviewed articles should be treated confidentially. The reviewers will be chosen in such a way that there is no conflict of interests with respect to the research, the authors and/or the research funders.

The editors have complete responsibility and authority to reject or accept a paper, and they will only accept a paper when reasonably certain. They will preserve anonymity of reviewers and promote publication of corrections, clarifications, retractions and apologies when needed. The acceptance of a paper automatically implies the copyright transfer to the National Academy of sciences of the Republic of Kazakhstan.

The Editorial Board of the National Academy of sciences of the Republic of Kazakhstan will monitor and safeguard publishing ethics. 
Правила оформления статьи для публикации в журнале смотреть на сайте:

\section{www:nauka-nanrk.kz}

\section{social-human.kz}

Редакторы М.С. Ахметова, Т.А. Апендиев, Д.С. Аленов

Верстка на компьютере А.М. Кульгинбаевой

Подписано в печать 08.12.2018

Формат 60x881/8. Бумага офсетная. Печать - ризограф.

17,7 п.л. Тираж 500. Заказ 6.

Национальная академия наук $Р К$

050010, Алматы, ул. Шевченко, 28, т. 272-13-18, 272-13-19 